\title{
Genetic Optimization of the Performance of the Solar Adsorption Refrigeration System for Iraq Climate
}

\author{
Nibal Fadel Farman, PhD \\ Energy Engineering Dept. \\ University of Baghdad \\ Baghdad, Iraq
}

\begin{abstract}
An optimization of the performance of the Solar Adsorption Refrigeration System unit with Genetic Algorithms (GA) is performed. A good design of the generator leads to smooth operation and better results, so more attention must be paid towards the design influence on the performance of the system, with respect to many factors that have an effect on the performance of adsorptive solar ice maker unit. These factors contain Geometrical factors, Concentration factor Operating factors and Climatic factors. Which play an essential role on the designed, constructed, tests and optimized the solar adsorption refrigeration system in order to confirm and achieve the possibility of the principles of solar adsorption refrigeration system and assess the amount of methanol percentage to the amount of activated carbon (A.C). This research is a part of $\mathrm{PhD}$ thesis. A field solar powered of ice maker unit designed, analyzed, built and tested, this unit was tested during three months from May till August 2012. The maximum (COP) of the solar adsorption system was 0.49 by ordinary calculation and 0.4883 by Genetic Optimization so there is compatible agreement between the classical method and Genetic Optimization. The concentration ratio X0 kg Methanol $/ \mathrm{kg}$ (A.C) of the present solar adsorption system was 0.29 as a result of the experimental work and 0.286 by genetic optimization. The maximum mass desorbed is approximately $600 \mathrm{~g} / 3 \mathrm{~kg}$ (A.C) which is a good quality for forming $1 \mathrm{~kg}$ of ice, when the average solar radiation in Iraq was $900 \mathrm{~W} / \mathrm{m} 2$.
\end{abstract}

\section{General Terms}

Genetic algorithms (GA).

\section{Keywords}

optimization; Refrigeration; Genetic; Solar energy ; activated carbon .

\section{INTRODUCTION}

According to the Montreal protocol on ozone layer depletion and the Kyoto protocol on global warming, the huge desirability of solar adsorption refrigeration is that its operational fluids verified its demand. The adsorption cooling systems need small amount of energy for working fluid which does not possess any problems of emission of greenhouse gases. Also solar-power-based refrigerator is not complex and is flexible for different size systems. The renewable energy sources, by use of ozone-friendly refrigerants and facility to use the adsorption systems can be favored as an alternate to the conventional refrigeration systems. Due to the increasing concentration of greenhouse gases and climate changes, global warming and ozone depletion layer, the need for renewable energy sources is greater than ever. [1]. There are several important reasons for considering solar energy as an energy resource to meet the needs of developing countries. First, most of the countries called developing are in or adjacent to the tropics and have good solar radiation available. Secondly, energy is a critical need of these countries but they do not have widely distributed, readily available supplies of conventional energy resources. Thirdly, most of the developing countries are characterized by arid climates, dispersed and inaccessible populations and a lack of investment capital and are thus faced with practically insuperable obstacles to the provision of energy by conventional means, for example, by electrification. In contrast to this solar energy is readily available and is already distributed to the potential users, Fourthly, because of the diffuse nature of solar energy the developments all over the world have been in smaller units which fits well into the pattern of rural economics. The factors which affect the availability of solar energy are: - Geographic location, Time of the day, Time of the year, Atmospheric conditions.[2].The application of solar energy instead of electricity to refrigeration appears logical for countries with a good supply of solar energy such as in IRAQ. In IRAQ, there is luck of electricity, but the solar irradiation is plentiful, thus the utilization of solar energy to produce cold in Iraq is very important. Iraq climate has an attractive potential for solar energy application .Iraq has excellent abundance of solar radiation, ranging from 1,800 to $2,390 \mathrm{KWH} / \mathrm{m} 2 / \mathrm{yr}$. of direct normal irradiation, and much of the flat Iraqi landscape is appropriate for solar plant, Iraq can taking the global lead in solar technology would demonstrate that the country's technical capacity is recovering, build Iraqi skills in a promising technology with significant export potential, and position Iraq as a leader in sustainability in the Middle East The adsorption cycle is changeable and not constant depending on some parameters, so there is no exact law which can followed so it must be have the experience by making more experimental and researches to get more information and experimental data about operating circumstances especially our bed is a new design and this prototype is new especially in Iraq. For the improvement of the system, a detailed computational and thermodynamic analysis must be carried out .The thermodynamic analyses of adsorption systems are complex, instead of solving complex differential equations and applying the limited number of experimental data, faster and simpler solutions can be obtained by using, GAs which is able to learn the key information patterns within multidimensional information domain. The use of GAs for the performance prediction and simulation of complex system is increasingly becoming popular in the last few years, [3].

\section{LITERATURE REVIEW}

An adsorption, also called a solid-sorption cycle, is a preferential partitioning of substances from a gaseous or liquid phase onto a surface of a solid substrate. This process involves the separation of a substance from one phase to accumulate or concentrate on a surface of another substance .An adsorbing phase is called an 'adsorbent'. Material, 
which is accumulated, concentrated or adsorbed in another surface, is called an 'adsorbate'. The sticking process should not change any macroscopic form of the adsorbent except the changing in adsorbent's mass. When the adsorbent (at temperature $\mathrm{T}$ ) is in exclusive contact with vapor of adsorbate (at pressure $\mathrm{P}$ ), an amount $\mathrm{m}$ of adsorbate is trapped inside the micropores in an almost liquid state. This adsorbed mass $\mathrm{m}$, is a function of $\mathrm{T}$ and $\mathrm{P}$ according to a divariant equilibrium $\mathrm{m}=\mathrm{f}$ $(\mathrm{T}, \mathrm{P})$. Moreover, at constant pressure, $\mathrm{m}$ decreases as temperature $(\mathrm{T})$ increases, and at constant adsorbed mass, pressure $(\mathrm{P})$ increases with $\mathrm{T}$. This makes it possible to imagine an ideal refrigerating cycle consisting of a period of heating/desorption /condensation followed by a period of cooling/ad sorption/ evaporation. [4, 5]

Reference [6, 7 and 8] in Morocco, tested adsorption icemaker with an activated carbon methanol pair system, machine in Burkina Faso which was commercially produced in the 1980s by the French company BLM. The machine presented a cooling performance about $35 \%$ higher than the machine tested in Morocco, [9] Estimated the overall heat transfer coefficient of the double function heat exchanger (condenser/evaporator) of a novel adsorptive solar ice maker (ASIM) with the help of an experimental data base. They showed that with a consistent design of the different components of this machine the daily ice production could exceed $5.2 \mathrm{~kg}$, with COPs of more than 0.14. [10] .at Shanghai Jiao Tong University SJTU research work on adsorption refrigeration in started in 1993; various adsorption refrigeration cycles have been investigated. [11]. Presented the thermodynamic design procedure for solid adsorption solar refrigeration and applied to systems using activated carbon/methanol, activated carbon/ammonia and zeolite/water adsorbent/adsorbate pairs. The results obtained showed that zeolite/water is the best pair for air conditioning application while activated carbon/ammonia is preferred for ice making, deep freezing and food preservation and study of the effects of different collector design parameters on the performances of a solar powered solid adsorption refrigerator. The refrigerator uses activated carbon/methanol as the adsorbent/refrigerant pair. Improvements in the ranges of $29-38 \%$ for COP and 26$35 \%$ for condensate yield. [12] Studied a solid adsorption refrigerator analysis using activated carbon/methanol pair. The presented results have been computed for an annular adsorber of outer radius $\mathrm{Re}=0.02 \mathrm{~m}$ and inner radius $\mathrm{Ri}=$ $0.01 \mathrm{~m}$, and length of $1.4 \mathrm{~m}$. The condenser and evaporator temperatures are assumed to be constant during the adsorption cycle. [13] Presented a design of a prototype of an air conditioning unit which is driven by solar energy using the adsorption technique. The adsorber is consisted of two beds each containing $5 \mathrm{~kg}$ of activated carbon. If heated to $110 \mathrm{oC}$, then the sensible heat needed to arise its temperature from room temperature to $110 \mathrm{o} \mathrm{C}$ would be around $900 \mathrm{~kJ}$. The solar energy used during the regeneration would be $43400 \mathrm{~kJ}$ and the theoretical COP would be 0.146. [14] Presented the design of new prototype of a solar adsorption refrigeration unit with certain specifications and requirements to be used as an air conditioning and refrigeration unit suitable to be used in remote areas. The gross cycle coefficient of performance, COP $\mathrm{a}=0.688$ from the thermodynamic calculations. $[15,16]$ designed and investigated the capability of solar adsorption system (SAR) in cooling system. a Fuzzy logic and regression analysis approaches were implemented to construct a multidimensional mathematical model to predict the coefficient of performance (COP) value of the SAR system as function of the evaporator, condenser, and generator temperatures and presented a statistical approach to analyze and to optimize the solar adsorption refrigeration unit for general applications and performed an experimental study on an adsorption refrigeration unit powered by a solar energy and equipped with three different types of activated carbon (1: Coconut, 2: Palm seeds, 3: Charcoal).

So from literature review it is clear that there is five topics are essential and significant for both developing a conventional adsorption refrigeration system literatures surveys are classified into main groups:-

1. Solar Powered Adsorption Application which is contains:

- Refrigeration for food, vaccines and medicines storage $(0-8 \circ \mathrm{C})$

- Air conditioning and chillers $\left(8-15^{\circ} \mathrm{C}\right)$

- Freezing and ice making $(<0 \circ \mathrm{C})$

- Heat Pipe in Adsorption Systems.

2. Design of an adsorbent bed for appropriate heat and mass transfer.

3. Experimental studies of adsorption cooling system contain:-

4. Modeling and simulation of solar adsorption system

5. Performance optimization and improvement.

\subsection{Performance Optimization and Improvement}

To improve the performance of solar adsorption system one must following one of the methods Experimentally, Analytically and Genetic algorithms researcher working in the above procedures $\left[\begin{array}{ll}17 & -22\end{array}\right]$. They working with the optimization of solar adsorption structure by fuzzy logic, genetic algorithm and artificial neural network statistical approach to analyze and to optimize the solar adsorption refrigeration unit such as Existing the plan of novel prototypical of a solar adsorption refrigeration section with confident specifications and necessities to be used as an air conditioning and refrigeration component proper to be used in faraway regions, in the following section the thermodynamically analysis will be set.

\section{SOLAR ADSORPTION COOLING TECHNOLOGIES}

The cycle is thus a four-temperature cycle. The construction of our SARS was done as a part of $\mathrm{PhD}$ degree. Refrigeration system consists essentially of: an evaporator, condenser, generator and solar collector. Fig .2 and 3 shows our field system and table .1 shows the dimensions of the prototype Solar Adsorption Refrigeration System (SARS).for more details about our SARS see ref [3].

Process $1 \rightarrow 2$ : Isosteric (constant $\mathrm{X}$ ) heating and pressurizing

Process $2 \rightarrow 3$ : Isobaric (constant $\mathrm{P}$ ) desorption and condensation

Process $3 \rightarrow 4$ : Isosteric (constant $X$ ) cooling depressurizing

Process4 $\rightarrow$ 1: Isobaric (constant $\mathrm{P}$ ) evaporation and adsorption.

A schematic of an ideal simple adsorption cycle is shown in Figure 1 .This is the only step in which cold is generated, it happens at a constant pressure dictated by the temperature in 
the evaporator and lasts until the early hours of the next morning. Mass adsorbate within the adsorbent reaches a maxim value at point $\mathrm{A}\left(\mathrm{x}_{\max }\right), \mathrm{Q}_{\text {Source }}=$ heat supplied the source; $\mathrm{Qs}=$ heat dissipated by the adsorbent; $\mathrm{Q}_{\mathrm{ad}}=$ heat of adsorption. [3].

\subsection{Kinetics and Thermodynamic Analysis of Adsorption Refrigeration Cycle}

The first law of thermodynamics is briefly reviewed and extended to the situation with heat generation/depletion in

1) Heating Process 1-2: The alteration of interior energy of the generator component can be written as:

The alteration in internal energy of the methanol is:-

$$
\begin{gathered}
\left.U_{\text {meth.1 }}=\text { intenergy methanol, } x=0, T=T_{1}\right) \\
U_{\text {meth.1 }}=\text { intenergy }\left(\text { methanol, } x=0, T=T_{1}\right) \\
U_{\text {meth.2 }}=\text { intenergy }\left(\text { methanol, } x=0, T=T_{2}\right)
\end{gathered}
$$

Therefore the total heat supplied in process $1-2$ is:

$$
\begin{aligned}
& Q_{C . M_{1-2}}=\left(\boldsymbol{m}_{\text {tube }} \cdot c_{\text {tube }}+\boldsymbol{m}_{\text {shell }} \cdot c_{\text {shell }}+\boldsymbol{m}_{\text {A.C. }} \cdot \boldsymbol{c}_{\text {A.C. }}\right)\left(\boldsymbol{T}_{\mathbf{2}}-\boldsymbol{T}_{\mathbf{1}}\right) \\
& +m_{\text {A.c. }} \cdot x_{\text {max }} .\left(U_{\text {meth. } 2}-U_{\text {meth. } 1}\right) \\
& Q_{C . M_{\cdot 1-2}}=\left(m_{\text {tube }} \cdot c_{\text {tube }}+m_{\text {shell }} \cdot c_{\text {shell }}+\boldsymbol{m}_{\text {A.C. }} \cdot c_{\text {A.C. }}\right)\left(T_{2}-T_{1}\right)+ \\
& m_{\text {A.C. }} \cdot x_{\max }\left(U_{\text {meth. } 2}-U_{\text {meth.1 }}\right)
\end{aligned}
$$

\section{2) Heating Process $2-3$ (Desorption Period):-}

Equation (6) represents the energy balance of the control volume (generally) since there is no work done.

$$
\begin{gathered}
\delta Q=\sum m_{e} h_{e}-\sum m_{i} h_{i}+\delta \dot{Q}+d U_{C V} \\
d H_{\text {meth.e }}=h_{\text {meth.e }} \cdot d m_{e} \\
\bar{h}_{g}=h_{\text {meth.e }}=\text { enthalpy }\left(\text { methanol, } x=1, T=\frac{T_{2}+T_{3}}{2}\right)
\end{gathered}
$$

Therefore: $\boldsymbol{H}_{\text {meth.e }}=\boldsymbol{m}_{\text {A.c. }} \cdot \Delta \boldsymbol{x} \cdot \overline{\boldsymbol{h}}_{\boldsymbol{g}}$

The average heat of adsorption can be taken as:

$$
\begin{array}{r}
\bar{h}_{a d}=R \cdot\left(A\left(\frac{T_{2}+T_{3}}{2}\right)-\ln P_{c}\right) \times \frac{T_{2}+T_{3}}{2} \\
+\frac{R\left(A\left(T_{2}\right)-\ln P_{c}\right) T_{2}}{2} \\
+\frac{R\left(A\left(T_{3}\right)-\ln P_{c}\right) T_{3}}{2}
\end{array}
$$

The increment in internal energy of the $\mathrm{CV}$ is:

$$
\begin{aligned}
& \Delta U_{\text {tube }_{2-3}}+\Delta U_{\text {shell }_{2-3}}+\Delta U_{A . C_{2-3}} \\
& =\int_{2}^{3}\left(m_{\text {tube }} \cdot c_{\text {tube }}+m_{\text {shell }} \cdot c_{\text {shell }}+m_{A . C .} \cdot c_{A . C .}\right) d T \\
& =\left(m_{-} \text {tube.c_tube }+m_{-} \text {shell.c } c_{-}\right. \text {shell } \\
& \left.+m_{-}(A . C .) \cdot c_{-}(A . C .)\right)\left(T_{-} 3\right. \\
& \left.-T_{-} 2\right)
\end{aligned}
$$

The modification of the inner energy of the refrigerant can be initiate using the following equation:-

$$
\begin{aligned}
& \Delta U_{\text {meth } \cdot 2-3}=\left(\boldsymbol{m}_{\text {A.C. }} \cdot \boldsymbol{x}_{\text {min }} \cdot U_{f_{3}}\right. \\
&\left.-m_{\text {A.C. }} \cdot x_{\text {max }} . U_{f_{2}}\right)
\end{aligned}
$$

Therefore, the net heat supplied in process $2-3$ is:

$$
\begin{aligned}
Q_{C . V .2-3}=m_{A . C .} \Delta & x \cdot \bar{h}_{g}+m_{A . C .} \Delta x \cdot \bar{h}_{a d} \\
& +m_{A . C .} \Delta x \cdot\left(U_{\text {meth }_{3}-} U_{\text {meth }_{2}}\right) \\
& +\left(\boldsymbol{m}_{\text {tube }} \cdot c_{\text {tube }}+\boldsymbol{m}_{\text {shell }} \cdot c_{\text {shell }}\right. \\
& \left.+\boldsymbol{m}_{\text {A.C. }} \cdot c_{A . C .}\right)\left(T_{3}\right. \\
& \left.-T_{2}\right)
\end{aligned}
$$

While the total heat supplied for the processes (1-2) and (2-3)

Is: $Q_{1-3}=\left(\boldsymbol{m}_{\text {tube }} \cdot \boldsymbol{c}_{\text {tube }}+\boldsymbol{m}_{\text {shell }} \cdot \boldsymbol{c}_{\text {shell }}+\boldsymbol{m}_{\text {A.C. }} \cdot \boldsymbol{c}_{\text {A.C. }}\right)\left(\boldsymbol{T}_{3}-\right.$ $\left.T_{1}\right)+m_{\text {A.C. }} \cdot x_{\text {max }}\left(U_{\text {meth. }}-U_{\text {meth. } 1}\right)+m_{\text {A.C. }} \Delta x \cdot \bar{h}_{g}+$ $\boldsymbol{m}_{\text {A.C. }} \cdot \Delta x \cdot \bar{h}_{a d}+\boldsymbol{m}_{\text {A.C. }} \cdot \Delta x \cdot\left(U_{\text {meth }_{3}-} U_{\text {meth }_{3}}\right)$

3) Cooling Process $3-4$

From state 3 to state 4 . The collector is cooled to the temperatureT4.

$$
\begin{aligned}
& \text { 4) Refrigeration Period 4-1 } \\
& \text { (Adsorption/Refrigeration Process): The } \\
& \text { energy balance of C.V. Is: } \\
& \delta Q=d U_{C V}+h_{e} \cdot d m_{e}
\end{aligned}
$$

The mass of the refrigerant at the beginning of the evaporation is:

$$
\begin{aligned}
m_{r_{0}}=m_{A . C .}\left(x_{\max }-x_{\min }\right)=m_{A . C .} \Delta x \\
x_{\text {min }}=x_{0} \exp \left\{-\left\{D \left[\left(A\left(T_{3}\right)-\ln P_{c}\right) T_{3}\right.\right.\right. \\
\left.\left.-B\left(T_{3}\right)\right]^{n}\right\} \quad(17) \\
x_{\text {max }}=x_{0} \exp \left\{-\left\{D \left[\left(A\left(T_{1}\right)-\ln P_{e}\right) T_{1}\right.\right.\right. \\
\left.\left.-B\left(T_{1}\right)\right]^{n}\right\}
\end{aligned}
$$

Therefore the net cooling [the cooling available for use] is:

$Q_{n e t}=m_{A . C .} \Delta x\left(h_{g_{e}}-u_{r_{0}}\right)-\left(m_{r e c} c_{r e c}+m_{e v} c_{e v}\right)\left(T_{c}-\right.$ $\left.T_{e}\right)-Q_{\text {leak }}$

COP Of the ideal cycle:

$$
\begin{aligned}
& \text { CoPnet }=
\end{aligned}
$$

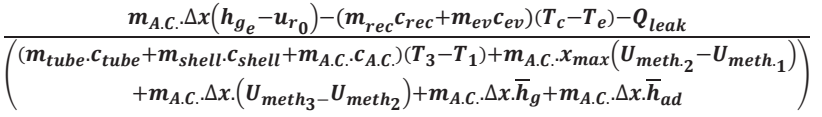

$$
\begin{aligned}
& \text { COPgross } \quad m_{\text {A.c. }} \Delta x\left(h_{g_{e}}-u_{r_{0}}\right)
\end{aligned}
$$

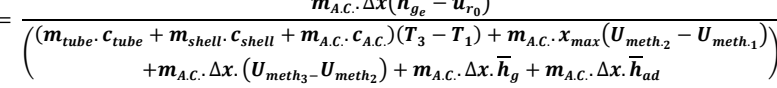

$$
\begin{aligned}
& X(P, T)=W_{0} \rho_{l} \exp \left\{-D\left(T \operatorname{Ln} \frac{P_{S}}{P}\right)^{n}\right\} D A \text { eq } .
\end{aligned}
$$

$\mathrm{COP}=$ Cooling effect/total energy input. [3].in the flowing section the object of this work with GA will be clear.

\section{THE GENETIC ALGORITHIM AND PRESNT WORK}

In a genetic algorithm, a population of strings (called chromosomes or the genotype of the genome), which encode candidate solutions (called individuals, creatures, or phenotypes) to an optimization problem, is evolved toward better solutions. Traditionally, solutions are represented in binary as strings of $0 \mathrm{~s}$ and $1 \mathrm{~s}$, but other encodings are also possible. The evolution usually starts from a population of randomly generated individuals and happens in generations. In each generation, the fitness of every individual in the population is evaluated, multiple individuals are stochastically selected from the current population (based on their fitness), 
and modified (recombined and possibly randomly mutated) to form a new population. The new population is then used in the next iteration of the algorithm. Commonly, the algorithm terminates when either a maximum number of generations has been produced, or a satisfactory fitness level has been reached for the population. A typical genetic algorithm requires:

- a genetic representation of the solution domain,

- a fitness function to evaluate the solution domain

1. Chromosome: a set of genes; a chromosome contains the solution in form of genes.

2. Gene: a part of chromosome; a gene contains a part of solution. It determines the solution. e.g. 16743 is a chromosome and 1, 6, 7, 4 and 3 are its genes.

3. Individual: same as chromosome.

4. Population: number of individuals present with same length of chromosome.

5. Fitness: the value assigned to an individual based on how far or close individual is from the solution; greater the fitness value better the solution it contains.

6. Fitness function: a function that assigns fitness value to the individual. It is problem specific.

7. Breeding: taking two fit individuals and then intermingling there chromosome to create new two individuals.

8. Mutation: changing a random gene in an individual.

9. Selection: selecting individuals for creating the next generation. [23], see fig.11.

This work research on the optimization of the performance with respect to the factors:-

A. Geometrical factors which includes the dimensions of the outside and inside diameters of the bed outer and inner daimeter $\left(\mathrm{D}_{\mathrm{O}}-\mathrm{D}_{\mathrm{i}}\right)$ and find the optimum thickness of the bed.

B. Concentration factor which clarify the optimum percentage of mass of Methanol in $\mathrm{Kg}$ to the mass of Activated Carbon in $\mathrm{Kg}$.

C. Operating factors which include the temperatures of starting, generation cycle (adsorption and desorption), T1 and $\mathrm{T} 3$.

D. Climatic factors which includes condensation and evaporation), Tc and Te which depends on the maximum temperature reached on the day and the minimum temperature reached on the night which determines the condensation pressure and evaporation pressurePc, andPe.

E. Then write a program in MATHLAB R2008a, in Genetic Algorithm to find the optimization of all above factors.

F. Then find the optimum values for the designing parameters and operation limits of solar adsorption refrigerator system which is suitable for Iraq climate

\section{RESULTS}

The optimum performance COP for each case with different parameters such $\left\{T_{1}, T_{2}, T_{3}, T_{4}, T_{c}, T_{e}, X_{\max }, X_{\max },\left(D_{O}-D_{I}\right)\right\}$. The figures (4) through (19), shows the optimization of the performance of our solar refrigerator for different values of the above parameters as one can see these values at the tables mentioned above. The result of these figures is the maximum performance $(\mathrm{COP})$ have get it is $0.4883 \cong 0.49$ at $X_{\max }=$ $0.27, X_{\min =0.091}, T_{1}, T_{2}, T_{3}, T_{4}, T_{c}, T_{e}$, equal $30.0916^{\circ} \mathrm{C}$, $44.0005^{\circ} \mathrm{C}, 60^{\circ} \mathrm{C}, 49^{\circ} \mathrm{C}, 25^{\circ} \mathrm{C}, 0^{\circ} \mathrm{C}$ respectively. So our operating conditions of $T_{1}=30^{\circ} \mathrm{C}, T_{2}=44^{\circ} \mathrm{C}, T_{3}=63^{\circ} \mathrm{C}$ and $T_{4}=48^{\circ} \mathrm{C}$ with $X_{\max }=0.29$ are very close to these resulting from Genetic optimization. Fig 4.b. proved the compatible of the result experimentally with genetic optimization for the concentration ratio.

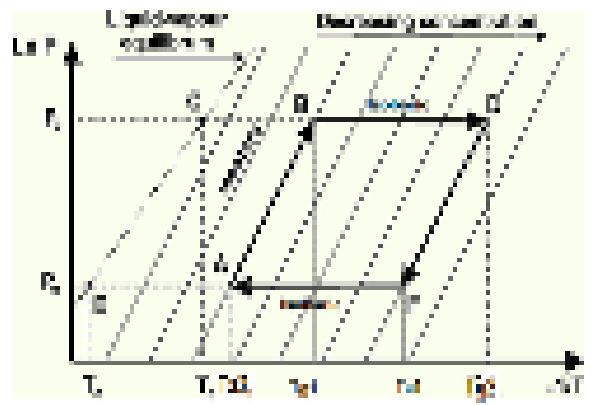

Fig.1 .Schematic diagram of solar adsorption refrigerator process

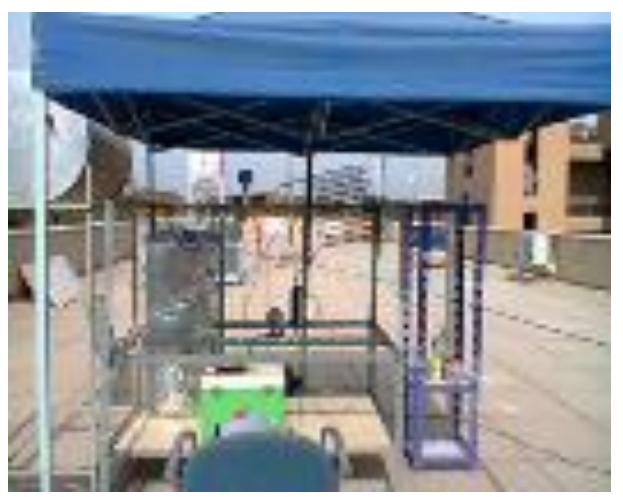

Fig. 2. Front view of solar adsorption refrigeration field system after installation

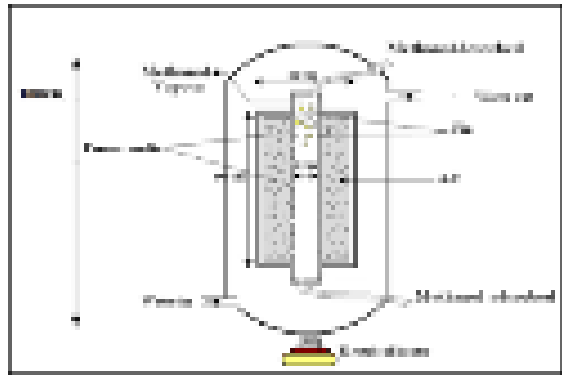

Fig.3. Generator Geometry with heat transfer vessel

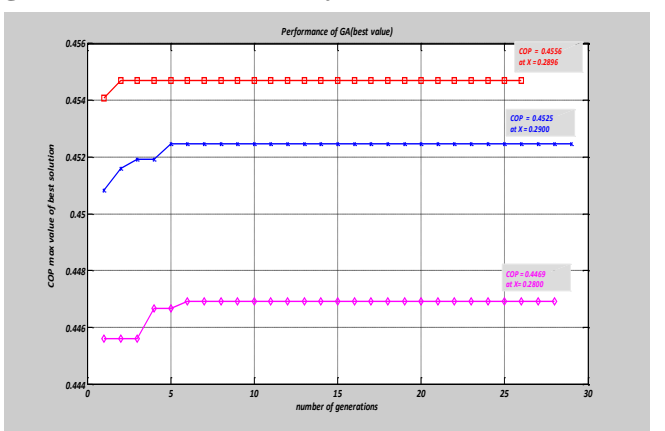

Fig.4.a. Optimum performance at different concentration ratio Xkg Methanol/Kg A.C. 


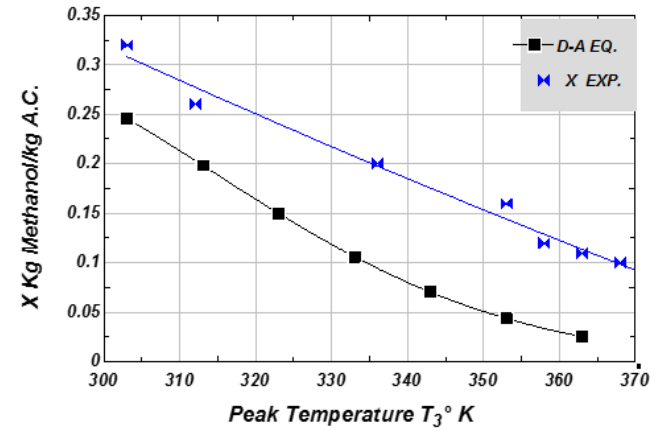

Fig.4.b. comparison of the experimental and theoretical Concentration [3]

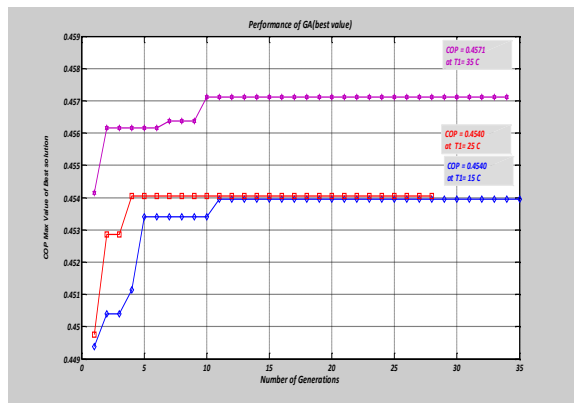

Fig. 5: Optimum performance at different starting temperature, it is clear that the optimum $C O P$ is 0.4571 at $T_{1}=35^{\circ} \mathrm{C}$.

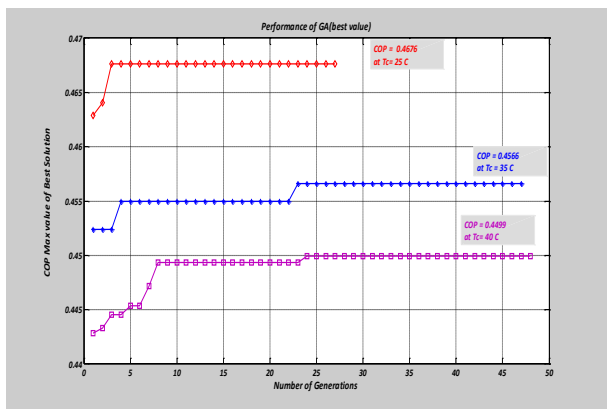

Fig.6: Optimum performance at different condensation temperature

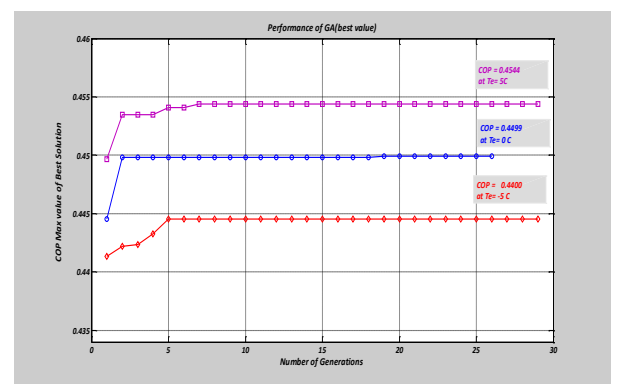

Fig.7: Optimum performance at different evaporating temperature, it is clear that the optimum $C O P$ is 0.4544 at $T_{c}=5^{\circ} \mathrm{C}$.

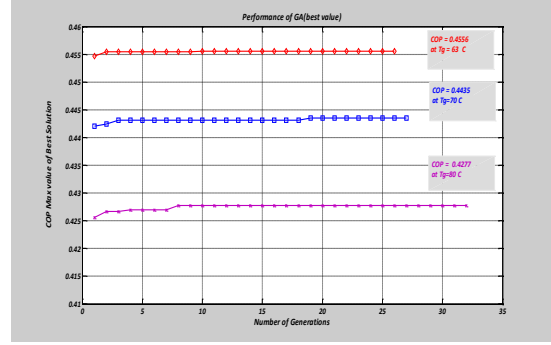

Fig.8: optimum performance for different generating peak temperatures, the optimum $C O P$ is 0.4556 at $T_{3}=63^{\circ} \mathrm{c}$.

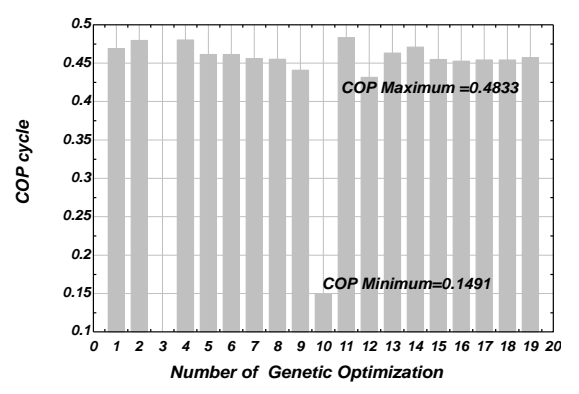

Fig .9: Maximum COP with the iteration maximum and minimum COP which getting from genetic optimization.

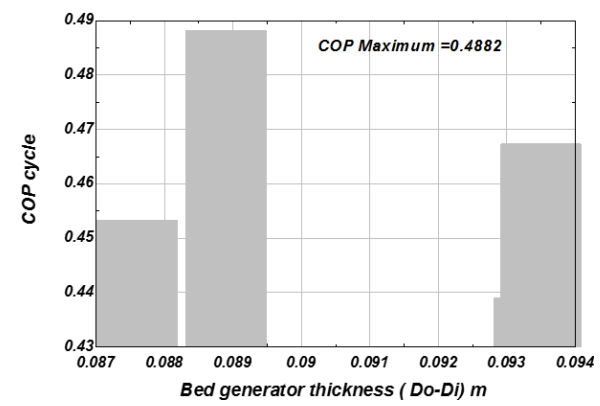

Fig .10: Maximum COP at different bed thickness

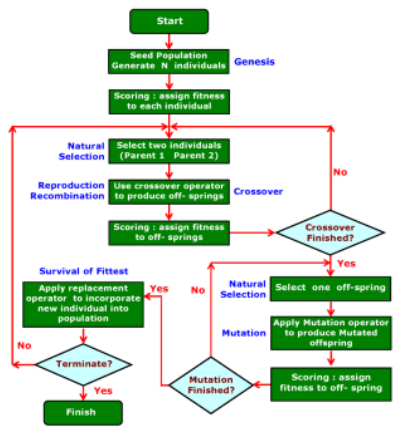

Fig.11.Genetic algorithm - program flow chart [24] 
Tabale.1 .Specification of the field solar adsorption refrigerator

\begin{tabular}{|l|c|}
\hline \multicolumn{1}{|c|}{ Bed ref.[3] } & cylindrical \\
\hline Outer diameter & $12 \mathrm{~cm}$ \\
Inner diameter & $2 \mathrm{~cm}$ \\
Length of the inner & $80 \mathrm{~cm}$ \\
cylindrical & $100 \mathrm{~cm}$ \\
Length of the bed & water \\
Fluid & $61 \mathrm{lit}$ \\
Volume of water & $870 \mathrm{~g}$ \\
Mass of methanol & $3 \mathrm{~kg}$ \\
Mass of granular activated & $\mathbf{0 . 4 8 8 3}$ \\
carbon & $1.4 \mathrm{w} / \mathrm{kg}$ \\
COP & Adsorbent \\
SCP & \\
\hline
\end{tabular}

Figure (10) represents the relation of the thickness of the bed generator with the performance; the system radius is an important parameter for system power per weight of adsorbent. It is clear from fig. that the optimum performance was with the (Do-Di) $=0.98 \mathrm{~cm}$ and the actual was $10 \mathrm{~cm}$ so it is very close and the results are as shown in Table 3. Increase in adsorbent thickness, the percentage of heat used to heat up the adsorbent becomes insignificant; the temperature in the center of the bed will be different from the wall of the bed i.e. the temperature distribution will be non-uniform, in table 2. The optimization iteration presented.

\section{DISCUSSION}

- All the results above of the genetic optimization of performance are compatible with previous results from $[1,3]$

- The maximum COP of the solar adsorption system was 0.49 by ordinary calculation and 0.4883 by Genetic Optimization so there is compatible agreement between the classical method and genetic optimization. The COP is close to the cop in ref [10].

- The concentration ratio Xo $\mathrm{kg}$ Methanol $/ \mathrm{kg}$ A.C of our solar adsorption system was 0.29 as a result of the experimental work and 0.286 by genetic optimization.

- The maximum mass desorbed is approximately $600 \mathrm{~g} / 3$ $\mathrm{kg}$ A.C which is a good quality for forming ice, which is close to ref [10].

- The increase in adsorbent mass signifies that more methanol being desorbed in that cycle. Hence, during desorption phase, the more methanol vapor can be desorbed, which produces more cooling in the cooling box. On the other hand, if the mass of the adsorbent is increased to more than 1.0 mass ratio, the cooling production decreases and the performance was minimum $=0.1491$ which can be caused deterioration in the system.

Table .2. Genetic Optimization Performance and Bed Diameter

\begin{tabular}{|c|c|c|c|c|c|c|c|c|}
\hline & Xmax g/kg & $\begin{array}{c}X \min \\
\mathrm{g} / \mathrm{kg}\end{array}$ & $\begin{array}{l}\text { T1 } \\
{ }^{\circ} \mathrm{C}\end{array}$ & $\begin{array}{c}\text { Do } \\
\text { m }\end{array}$ & $\begin{array}{l}\text { T3 } \\
{ }^{\circ} \mathbf{C}\end{array}$ & Tc ${ }^{\circ} \mathrm{C}$ & $\begin{array}{l}\text { Te } \\
{ }^{\circ} \mathrm{C}\end{array}$ & $\begin{array}{c}\text { COP } \\
\text { optimum }\end{array}$ \\
\hline \multirow{3}{*}{1} & .26 & .05 & 15 & 0.08 & 63 & 25 & -10 & \\
\hline & .28 & 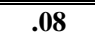 & 35 & 0.1 & ב63 & ב40 & 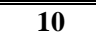 & \\
\hline & 0.2728 & ב.0664 & 35. & 0.0935 & 63. & 25. & 9.0719 & 0.4673 \\
\hline \multirow{3}{*}{2} & .26 & .05 & 15 & $\begin{array}{l}0.08 \\
\end{array}$ & 70 & 25 & -10 & \\
\hline & . .28 & $\bar{~} .08$ & 35 & 0.1 & $7 \overline{70}$ & 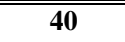 & 10 & \\
\hline & 0.2738 & ב.0681 & 35. & 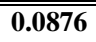 & 70. & 25. & 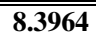 & 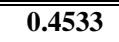 \\
\hline \multirow{3}{*}{3} & .26 & $\bar{~} .05$ & 15 & 0.08 & 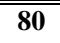 & 25 & $\overline{-10}$ & \\
\hline & .28 & .08 & 35 & 0.1 & 80 & 40 & 10 & \\
\hline & 0.2759 & 0.0647 & 35. & $\begin{array}{c}0.0934 \\
\end{array}$ & 80. & 25.0396 & 9.4227 & (2.4390 \\
\hline \multirow{3}{*}{4} & $\bar{~} .26$ & 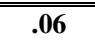 & 15 & $\overline{0.08}$ & 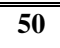 & 25 & -10 & \\
\hline & .28 & .08 & 35 & 0.1 & 100 & 40 & 10 & \\
\hline & 0.2782 & 0.0658 & 35. & 0.0889 & 50. & 5.7061 & 4.3417 & 0.4882 \\
\hline
\end{tabular}

\section{CONCLUSION AND FUTER WORK}

The prototype, is built so it acceptable to improvements: like added another beds it will be continuous refrigerator, or added a fan or cooler to cool the condenser by forced convection, or change the bed to be horizontal, change the solar collector, the working pair and for all these improvement so one can optimize the performance and make compression between them. And using new adsorbent pair with new bed design and using fan to cooling the condenser to get better efficiency with $\mathrm{GA}$, and improve the performance by using two bed continuous solar cooling system. 


\section{REFERENCES}

[1] Simon, Louise Jivan Shah, Ulrike, Jordan, (2003)." Solar Energy State of the Art" Internal Report, BYG•DTU SR03-14. Denmark Tekniske University.

[2] [http://www.redsolar.biz/energy-efficiency.php].

[3] Nibal F.Farman ," Performance of the Solar Adsorption Refrigeration System under Various Conditions and Parameters for Iraq Climate",2013 , A thesis Submitted to the Energy Engineering Department, College of Engineering, University of Baghdad in Partial Fulfillment of the Requirements for the degree of Doctor of Philosophy in Energy Engineering.

[4] Kalkan Naci , Young EA , Ahmet Celiktas." Solar Thermal Air Conditioning Technology Reducing The Footprint Of Solar Thermal Air Conditioning", Renewable And Sustainable Energy Reviews 16 (2012) $6352-6383$.

[5] Wimolsiri Pridasawas."Solar Cooling", Royal Institute Of Technology, Stockholm, Sweden June 27, 2003 Assignment for Ph.D. Course: Solar Heating Technical University of Denmark (DTU).

[6] Boubakri A , Arsalane M , Yous B , Ali-Moussa L , Pons M , Meunier F And Guilleminot JJ , (1992) ." Experimental Study of Adsorptive Solar Powered Ice Makers in Agadir (Morocco) I Performance in Actual Site. Renewable Energy 2, 7-22.

[7] Boubakri A , Arsalane M , Yous B , Ali-Moussa L , Pons M , Meunier F And Guilleminot JJ, (2000) . "Adsorptive Solar Powered Ice Maker: Experiments And Model (Morocco) II. Solar Energy Vol. 69, No. 3, PP. 249-263.

[8] Boubakri A, (2003)."A New Conception of an Adsorptive Solar-Powered Ice Maker ", Renewable Energy 28, 831-842.

[9] Boubakri A, (2006)."Technical Note. Performance Of An Adsorptive Solar Ice Maker Operating With A Single Double Function Heat Exchanger (Evaporator/Condenser)", Renewable Energy 31, 1799 1812.

[10] Wang R Z."Adsorption Refrigeration Research In Shanghai Jiao Tong University", Institute Of Refrigeration And Cryogenics, Shanghai Jiao Tong University, Shanghai 200030, China, Vol 5,P 1-37, 2001

[11] Anyanwu EE, Ogueke NV, (2009). "The Performance Analysis of a Solid Adsorption Solar Refrigerator during Collector Cool-Down and Refrigerant Evaporation/ReAdsorption Phases", Vol. 223 Par T E: J. Process Mechanical Engineering.

[12] Allouache N, Bennacer R, Chikh S and Al Mers A."Numerical Analysis of Heat and Mass Transfer in an Annular Porous Adsorber for Solar Cooling System", Defect and Diffusion Forum Vols. 297-301 (2010) Pp 802-807.

[13] Sahmarani K J, Obied F K and El-Samni O A, (2010)." Proposal For An Adsorption Solar-Driven AirConditioning Unit For Public Offices", Proceedings Of The Tenth International Conference Enhanced Building Operations, Kuwait, October 26-28.
[14] Abu Hamdeh H. Nidal, Al-Muhtaseb Mutaz A., (2010)."Optimization Of Solar Adsorption Refrigeration System Using Experimental And Statistical Techniques",Energy Conversion And Management.

[15] Tashtoush Ghassan M. \& Mohannand Al-Ata \&Atif AlKhazali, (2010)."Solar Adsorption Refrigeration (SAR) System Modeling", Jordan, Energy Efficiency", DOI 10.1007/S12053-010-9091-5.

[16] Tashtoush Ghassan M., Bourhan M, Mustafa M. Jaradat, (2012)." Experimental Study of A Solar Adsorption Refrigeration Unit, Factorial Analysis", Irbid, Jordan Smart Grid and Renewable Energy, 3, 126-132.

[17] Baiju V and Muraleedharan C, (2012)."Performance Prediction of Solar Adsorption Refrigeration System by ANN", International Scholarly Research Network ISRN Thermodynamics, Volume, Article D102376, 8 Pages.

[18] Norhafizah Ahmad Junaidi*, Tohru Suwa , 78: 5-8 (2016) 101-107 | www.jurnalteknologi.utm.my | eISSN 2180-3722 |

[19] 1Umesh Patel; 2Prakash Kumar Sen \& 3Ritesh Sharma ,e-ISSN: 2348-6848, p- ISSN: 2348-795X Volume 2, Issue 11, November 2015.

[20] Prashant S. Pathak1, Harshal J. Badhe2, Asif S. Shaikh3, Kunal A. Chhattiskar4, Pratik P. Thakur5, Ashwinikumar S. Patil*, International Journal of Science, Engineering and Technology Research (IJSETR) Volume 06, Issue 04, April 2017, ISSN: 2278 -7798.

[21] Prof B. M. Dusane1, Prof. N.C. Ghuge, ISSN (e): 22503021, ISSN (p): 2278-8719 Vol. 06, Issue 11 (Nov 2016), ||V1|| PP 07-13.

[22] Maamar Laidi, Salah Hanini, (2012)."Prediction Of Solar Adsorption Refrigeration System Performance Using Ann Based On Genetic Learning ", International Journal Of Engineering Science And Technology (IJEST) Vol. 4 No.08 August.

[23] [http://en.wikipedia.org/wiki/Genetic_algorithm].

[24] [www.myreaders.info/html/artificial_Intelligence.Html].

\section{APPENDIX}




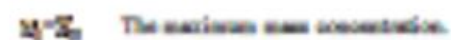

58

Ginet lasers:

a Demed affaikby or dewpiby.

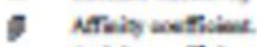

7 Nativity warkin:

a Ouserianmeto

* Viancis

- Dewiry

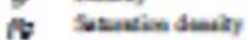

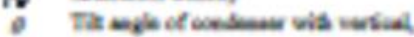

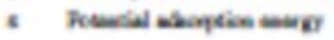

\begin{tabular}{|c|c|}
\hline \multicolumn{2}{|c|}{ Soburipe } \\
\hline AWE. & Aofivend uthen. \\
\hline 분 & Naveglise quably. \\
\hline c & saclites \\
\hline$\theta$ & Caesol walues \\
\hline and & Cusbestase \\
\hline anein & Canbese inget \\
\hline wevent & Condmeser ant \\
\hline$\omega$ & 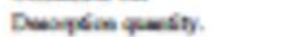 \\
\hline $\mathbf{a}$ & Rutes. \\
\hline $\boldsymbol{f}$ & nas, \\
\hline 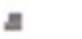 & $s=$ \\
\hline 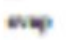 & sucperatis \\
\hline 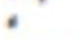 & staperabe vid nepeses \\
\hline nowat & gues cowisy. \\
\hline 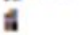 & inktea. \\
\hline i & tiepat \\
\hline ver & iscenaligy. \\
\hline$r$ & resigente: \\
\hline $\mathbf{z}$ & Vaper. \\
\hline
\end{tabular}

\section{Line:}

Leis

Liva

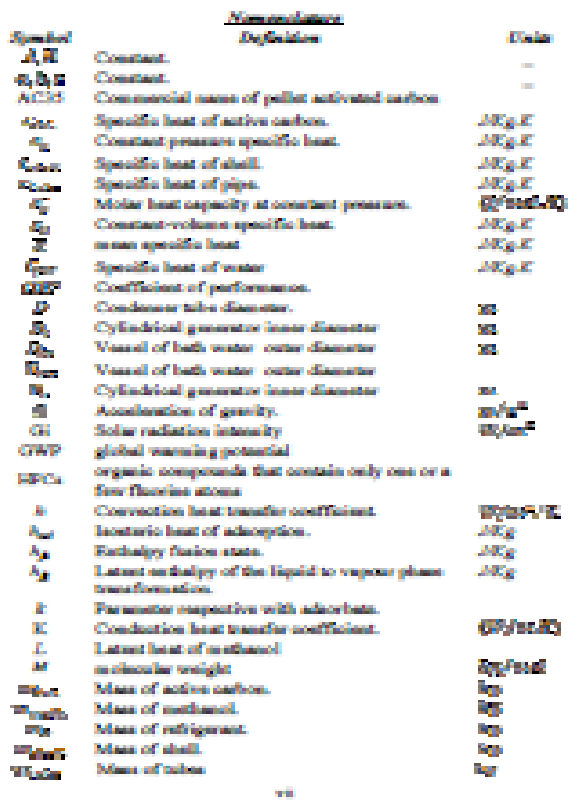

